\title{
article SHAPING INFORMATION AT DIGITAL NATIVE NEXO IN THE SCENARIO OF JOURNALISTIC CONVERGENCE
}

GABRIEL RIZZO HOEWELL

Universidade Federal do Rio Grande do Sul, Porto Alegre - Rio Grande do Sul-Brazil

ORCID: 0000-0002-6140-6800

ANA GRUSZYNSKI

Universidade Federal do Rio Grande do Sul, Porto Alegre - Rio Grande do Sul-Brazil

ORCID: 0000-0001-8840-0153

DOI: 10.25200/BJR.v16n2.2020.1257

Received in: October 10 $10^{\text {th }}, 2019$

Desk Reviewed: November, 24th 2019

Desk Review Editor: Laura Storch

Revised on: January $1^{\text {st }}, 2020$

Approved on: March $3^{\text {rd }}, 2020$

\begin{abstract}
The native digital newspaper Nexo is the empirical object of analysis of this study that aims to understand how its journalistic information is structured in terms of sections, themes, web potential, modalities, genres, and journalistic formats. The theoretical framework consists of the scenario of journalistic convergence, the structural changes and innovations associated with this convergence, and understanding the newspaper as a device, paying attention to the characteristics of cyberjournalism and how the newspaper was formed. The methodological procedures adopted are bibliographic and documentary researches and content analysis, which operationalize the evaluation of the corpus composed of materials collected in five spaces between September 11 and 24, 2017 - sections of the website, home page, Facebook page, newsletters and articles. There is a new proposal for framing sections and themes; distinct approaches to periodicity, topicality, universality and advertising; multiplatform articulation; exploration of different modalities, formats and genres; adoption of hypertextuality and memory for explanatory journalism; and the use of multimedia and interactivity as alternatives for editorial innovation.
\end{abstract}

Key words: Cyber journalism. Nexo Newspaper. Journalistic convergence. Digital native. Explanatory journalism. 


\section{A CONFIGURAÇÃO DA INFORMAÇÃO NO NATIVO DIGITAL NEXO NO CENÁRIO DE CONVERGÊNCIA JORNALÍSTICA}

RESUMO - O jornal nativo digital Nexo é o objeto empírico de análise que visa averiguar como se dá a conformação editorial da informação jornalística no veículo tendo em vista seções e temas, potencialidades da web, modalidades, gêneros e formatos jornalísticos. $\mathrm{O}$ quadro teórico compreende o cenário de convergência jornalística, as mudanças estruturais e inovações a ele associadas e a apreensão do jornal enquanto dispositivo, atentando para especificidades do ciberjornalismo e da conformação do ciberjornal. Os procedimentos metodológicos adotados são as pesquisas bibliográfica e documental e a análise de conteúdo, que operacionalizam a avaliação do corpus composto por materiais coletados entre 11 e 24 de setembro de 2017, em cinco espaços - seções do site, home, página do Facebook, newsletters e matérias. Observa-se uma nova proposta de enquadramento em seções e temas; abordagens distintas para periodicidade, atualidade, universalidade e publicidade; articulação multiplataforma; exploração de modalidades, formatos e gêneros diversos; adoção de hipertextualidade e memória para jornalismo explicativo; e uso de multimidialidade e interatividade como alternativas de inovação editorial.

Palavras-chave: Ciberjornalismo. Jornal Nexo. Convergência jornalística. Nativo digital. Jornalismo explicativo.

\section{LA CONFIGURACIÓN DE LA INFORMACIÓN EN EL NATIVO DIGITAL NEXO EN EL ESCENARIO DE CONVERGENCIA PERIODÍSTICA}

RESUMEN - El periódico nativo digital Nexo es el objeto empírico de la análisis que tiene como objetivo determinar cómo és la conformación editorial de la información periodística en el vehículo, considerando las secciones y los temas, los potenciales de la web, las modalidades, los géneros y los formatos periodísticos. El marco teórico comprende el escenario de la convergencia periodística, los cambios estructurales y las innovaciones asociadas con él, la aprehensión del periódico como un dispositivo, en vista de las especificidades del ciberperiodismo y la conformación del ciberperiódico. Los procedimientos metodológicos adoptados son la investigación bibliográfica y documental y el análisis de contenido, que ponen en práctica la evaluación del corpus compuesto por materiales recopilados entre el 11 y el 24 de septiembre de 2017, en cinco espacios: secciones del sitio, página de inicio, página de Facebook, boletines informativos y artículos. Hay una nueva propuesta para enmarcar secciones y temas; enfoques distintos de periodicidad, actualidad, universalidad y publicidad; articulación multiplataforma; exploración de diferentes modalidades, formatos y géneros; adopción de hipertextualidad y memoria para periodismo explicativo; y el uso de multimedia e interactividad como alternativas para la innovación editorial.

Palabras clave: Ciberperiodismo. Periódico Nexo. Convergencia periodística. Nativo digital. Periodismo explicativo.

\section{Introduction}

The changes to journalism brought on by the inclusion of social media platforms and the ubiquity of the internet made possible by the popularization of mobile devices are both fundamental aspects towards understanding today's journalism. This article discusses these reconfigurations based on the multidimensional approach to journalistic convergence proposed by Salaverría et al. (2010), which 
affects the editorial, professional, business and technological areas of the field. Research on structural changes (Pereira \& Adghirni, 2011 ) and paradigms shift in the field (Charron \& De Bonville, 2016) were also looked at in this proposal. The perceptions of space and time in society are also discussed in order to better understand today's journalism.

The empirical object of this study is the native digital site Nexo, created in November 2015. Nexo is the first Brazilian independent media organization to win the Online Journalism Awards and was voted second-best news website in the world at the World Digital Media Awards 2019. It gained prominence in national journalism for its different approach to daily news using explanatory journalism for contextualizing information. At the Online Journalism Awards, Nexo was praised as an "innovative approach to narratives in short and long texts, with interactive and integrated high quality journalism, and a creative dedication to inform and satisfy audiences on a variety of platforms" (Nexo Jornal, 2017).

We analyze how this digital native newspaper shapes journalistic information by articulating sections and themes, web potential, modalities, genres, and journalistic formats on its website, Facebook page and newsletters (data collected in September 2017). The objective is to understand transformations that have occurred to journalism, using Nexo as a model vehicle to reflect on the configuration of information in this scenario of convergence. In order to do this, a content analysis was made, structured around the discussion about the editorial transformations of a (cyber) newspaper, going from the concept of a device (Mouillaud, 1997; Charaudeau, 2009) to the debate on the potentials of cyber journalism, and the structuration of its products in editorials, sections, genres and journalistic formats.

The proposed approach uses the editorial sphere as its starting point, understanding that it is inseparable from the others and reflects the decisions taken in the professional, business and technological realms. As Bardin (1977) points out, content analysis provides knowledge of production conditions by using indicators, whether quantitative or not. One must first describe the object in order to understand its relationship with the environment in which it is inserted, seeking to identify how the forces pointed out in the theoretical framework act on the object. 


\section{Reconfigurations of journalism}

We cannot fully understand contemporaneity merely from the features of new media. As Crary (2014) proposes, it is important to think not only about the functional aspect and effects of smartphones and social networks, but also about how our experience and perception are reconfigured with the accelerated and intensified pace of consumption that these devices bring. Thus, it is important to understand the characteristics of journalism in the current scenario of convergence, the different dimensions of this process, and the change to its paradigm and normative system (Charron \& De Bonville, 2016). The key is to think about journalism as constantly changing, based on an ontology of becoming rather than an ontology of being (Deuze \& Witschge, 2015).

Salaverria et al. (2010) point to the integration of tools, spaces, working methods and languages, and content designed with multiplatforms in mind, using the most appropriate language for each one. In terms of technology, there is different electronic media which changes the form of access and opens up new ways of presenting information. In terms of economy, there is a consolidation of large companies and vertical integration in the media industry. "Audiences have more sources than ever for news and information, yet, at the same time, financial control of those sources is being concentrated in fewer entities" (Kolodzy, 2009, p. 47).

Economic, political, cultural and social changes have led to increased innovation, causing previously established paradigms to become outdated, and thus leading to new discursive practices (Charron \& De Bonville, 2016). Pereira and Adghirni (2011) see structural changes in contemporary journalism. For Spenthof (2015), it is information of public interest, one which is current, true, plural, impersonal and objective, that structures journalism - removing this would be its undoing. Professional mediation (carried out by a reading contract), organizational mediation (whether commercial, state or civil society organization), and technological mediation, which allows for a wide range of communication, are all structural. The challenge lies in understanding how social conditions affect the praxis of journalism, how it changes these structural pillars - and even the structuring base - and modifies their speech and symbolic recognition.

Salaverría (2015) points to five fundamental divisions: borders (because information is disseminated in a network); barriers (of 
a technological, financial and legal nature, for accessing the media market); editorial cycles (with the proliferation of supports); a monopoly of words (with more horizontal, multidirectional and simultaneous dialogue); and business models (given the difficulty of sustaining itself being based on the sale of content). These are phenomena that have emerged with the rise of mass self-communication media (Castells, 2015). Interpersonal communication, mass communication and mass self-communication coexist and interact, articulating in a digital hypertext that re-combines the cultural expressions transmitted by human interaction (Castells, 2015).

In a networked society, technologies and networks put social structure trends into practice (Castells, 2015). In this sense, timespace compression (Harvey, 1992) is essential towards understanding these changes in journalism. Acceleration and volatility have become hallmarks of this social structure, especially with the advance of computers. The perspective is close to what Crary (2014) presents when he talks about 24/7 time, something which is continuous, which accumulates and is excessive, and which masks the end of periodicity. According to Castells (2015), the relationship with time in a networked society is defined by the use of technologies in an attempt to do away with time by denying sequencing. Han (2017) points out that the problem is not acceleration, which has already come and gone, but a temporal dispersion which has acceleration as one of its symptoms, but its cause is dyschronicity. What is missing is a rhythm that can provide order. Time goes on without direction, atomized and discontinuous, with nothing connecting events to allow them to last. In this context, narratives, which presuppose a closed time, are lost amid a succession of events that focus on the present and speed up and slow down time. As stated by Han (2017), the movement on the internet is not marching or walking, but surfing or navigating, which refer to movements without any predefined direction.

The transformations that journalism and society have undergone have provided the conditions for hyper-competition marked by short life cycles of products, constant changes and instabilities. In this state of hyper-competition, the market not only has an extrinsic influence on journalistic products, such as price, quantity and placement in the market, but on its own nature (Charron $\&$ De Bonville, 2016). The time available for media consumption is shorter while the amount of information is increasing. Each individual 
builds his or her own daily news cycle, and learns in different spaces and times (Kovach \& Rosenstiel, 2014).

In hyper-competition, innovation becomes a key factor, one which is further accentuated by the development and diffusion of technologies (Nunes \& Canavilhas, 2020). For Martins (2017, p.3, our translation), "innovation in journalism can be understood through several aspects, whether narrative forms, production processes, technological and/or interactive devices, or even the stages of information circulation and consumption". According to Machado (2010, p. 67, our translation), innovation in journalism is "any change in techniques, technologies, processes, languages, formats, teams, devices and applications, or business values or models designed to streamline and enhance the production and consumption of journalistic information". Bertocchi (2017, p.106) argues that the innovation of a journalistic enterprise occurs with a singularity that breaks from the pre-established models of "teams, strategies, processes, narrative formats, audiences and technologies". However, individual innovations created to meet immediate needs and specific strategies will not help journalism overcome the instability it currently experiences; we need to think about the media ecosystem as a whole and think about innovations in an interconnected way, with replicability for different contexts (Nunes \& Canavilhas, 2020). Barbosa (2012) understands mobile devices, databases and multiplatform journalism as being agents of innovation and reconfiguration in convergent journalism, structuring dynamic products with context and depth, and new aesthetic standards for viewing information.

Many barriers have been overcome in order to enter the market of cyber journalism. This has led to an increased number of digital native journalistic startups ${ }^{2}$ that fill the gaps left by traditional media but still seek a sustainable economic model (Anderson et al., 2016; Deuze, 2017). Digital natives help to renew traditional values of journalism (Harlow \& Salaverría, 2016) by investing in their own content and in the aggregation of content from other vehicles, collaborators and readers (Anderson et al., 2016). The reconfigurations of journalism experience these initiatives, which propose new ways of doing journalism (Anderson et al., 2013). According to a study by Schiffrin (2019), the main challenge for these startups, especially in the global south, is economic survival; they rely on donations and receive little revenue from advertisers and audiences. Membership models (where the public is not just a subscriber, but can also 
participate in events and in journalistic production, as well as receive exclusive content) are a trend but, according to the author, are difficult to scale. The 2020 Reuters Institute report shows that media vehicles continue to rely on readers as their main source of revenue (Newman, 2020).

In addition to the financial crisis of the business model, Mick and Tavares (2017) identify a crisis of journalism governance due to the public's increasing lack of credibility in journalistic companies. Resolving this crisis would involve fostering new relationships between journalists and audiences in order to restore the credibility of discourse. The recent changes and technological advances that can more accurately measure audiences place the public at the center of journalistic production, more than ever before. Audience metrics impact production in terms of attitudes, behaviors, content, discourse and ethics (Zamith, 2018). In addition, media vehicles are relying more and more on personalized websites and automatic recommendations, with investment in artificial intelligence (Newman, 2020).

What Anderson et al. (2013, p.32, our translation) call post-industrial journalism is based on the principle that current institutions will need to "take advantage of new working methods and processes afforded by digital media" in order to remain relevant. Barsotti (2014) argues that the role of journalists in this environment is called into question, and their functions are reconfigured: the roles of gatekeeper, gatewatcher, mediator and mobilizer of the audience overlap. Kovach and Rosenstiel (2014) believe that, today, it is up to journalists to produce meaning from the events they put into context.

The desire to make the world intelligible goes hand in hand with the development of journalism. In this regard, it is worth saving explanatory journalism. Parisi (1999) defines explanatory journalism as providing a historical, sociological, and economic context for current events. Forde (2007, p.227) speaks of "an explanation and interpretation of complex events and phenomena placed in social, political, or cultural context". Norris (2015, online) summarizes it as: "if news content focuses on the 'Who, What, When and Where', explanatory journalism looks to inform the reader of the 'How and Why"'.

Despite the differences in nomenclature and the blurry line that divides explanatory journalism from interpretive journalism, we choose explanatory journalism as adopted by Nexo. By using this term we refer to the journalism that seeks the "how and why". 
Another fundamental aspect in understanding this scenario is the consolidation of social media platforms as publishers. Bell and Owen (2017) identify three significant changes to journalism business and distribution models over the past twenty years: the switch from analog to digital; the rise of the social web; and the current dominance of mobile. In this last phase, technology companies dominate the market and have forced news organizations to rethink their processes and structures. Facebook, Instagram, Twitter, and Google have moved on from their role as content distributors to that of publishers, controlling audiences and shaping journalistic formats (Bell \& Owen, 2017). Newspapers thus outsource their publications to these platforms, which has an effect on their content as it is shaped according to what works best on their platforms.

\section{Editorial configuration of cyber journalistic products}

Mouillaud (1997) states that a newspaper's discourse is always wrapped up in a device. Devices are matrices that articulate content and frame discourse; they give meaning. More than just a support, devices represent material or immaterial places in which texts - not only written - are inscribed. Thus, when referring to devices, we are referring to the semiotic power and limitations that it provides when formatting content of different modalities (Gruszynski, 2016).

Whether a device is considered a material or immaterial place involves thinking of two concepts (material and immaterial) for newspapers (Hoewell, 2018). For Groth (2011), as a uniform whole, the newspaper is immaterial, because it is not somewhere in space, nor can it be perceived through the senses. It is a cultural work whose meaning is in its substance that is materialized in each copy. If it is only understandable through each material, the form and technical production are fundamental to the editorial structure of a newspaper.

This substance that defines the newspaper is, for Groth (2011), the purpose of mediating the communication of immaterial goods and is characterized by publicity, universality, periodicity and topicality. However, materiality is understood as having a significant role in delineating these characteristics. If perceptions of time and space are altered by technological, economic and cultural changes, the characteristics of a newspaper are also affected. After all, periodicity and topicality are linked to the subject's relationship with time, and 
universality and publicity concern the subject's relationship with space. Thus, if space and time cannot be understood from an objective scale, but from the practices and concepts that each social formation incorporates, these characteristics can be changed depending on the conditions in which they materialize (Hoewell, 2018).

Not only do the characteristics of the immaterial whole proposed by Groth (2011) undergo changes, but elements of the material newspaper also change in the context of convergence. This "newspaper material device" shapes the text by framing them in sections and themes, and arranges content in a hierarchical form. These sections influence interpretations - using titles that establish pre-agreements (Mouillaud, 1997) - allowing one to understand how the vehicle constructs public space. The newspaper cuts universality by framing it in themes or sections, whereas a cyberjournal can use the database to organize the information.

Traditionally, a newspaper is divided into editorials which are in turn based on themes. This results in separating professionals inside the newsroom and separating the newspaper product, dividing it into sections and booklets that relate to each editorial. Traditional editorials include politics, economics, sports, culture, and others.

In addition to these sections, the newspaper's page or website is composed in such a way that allows for readers to make inferences, establishing meaning relationships (Gruszynski, 2011) depending on how the device shapes this information. The design enables identity relationships between sections or themes and provides a hierarchy of information. The front page, which was a form for printed newspapers to encourage one to purchase its periodical (Gruszynski, 2011), is now replaced on the web by the homepage. The increased number of smartphones and news consumption on social networking sites make the homepage invisible (Barsotti \& Aguiar, 2017). Links to social networks and search engines have become the main source for accessing news, which helps reduce the traffic on homepages. Shaped by other devices, such as Google and social media platforms, the article no longer establishes relationships only with what is close to it at home, but with what surrounds it in a news feed or in search results. Even so, a homepage still "translates" the newspaper (Barsotti \& Aguiar, 2017).

Another factor that adds to this invisibility of homepages is the return to newsletters. According to Carr (2014), in the fragmented and overabundant scenario of information, readers get tired of the infinite flow of content and see the newsletter as an opportunity to have order in 
chaos. Additionally, newsletters re-establish a closer contact with readers through email, potentially strengthening their engagement, as opposed to the intermediated environment of social media platforms (Hendrickx et al., 2020). Fagerlund (2015) has seen journalistic newsletters expanding since 2012 , driven by digital natives. It is worth mentioning curated newsletters here. To curate means to mediate and not to produce, but to aggregate existing elements, guiding the production of meaning from new relationships (Ramos, 2012). News curation involves selecting, hierarchizing, contextualizing and formatting news from one or more vehicles, and is performed by algorithms or humans.

Different logics for printed models emerged with digitization, and social networks and search engines added new information flows in multidimensional hypertextual architectures (Gruszynski, 2016). Multiple communication formats were made possible by internet resources and, gradually, a language specific to the medium was established (Mielniczuk, 2003), one marked by interactivity, hypertextuality, multimedia, memory, instantaneousness, personalization and ubiquity (Canavilhas et al., 2014).

\section{Nexo}

Created on November 24, 2015, Nexo ${ }^{3}$ is a digital newspaper that offers explanations, contextualized information and interpretations about the main events in Brazil and the world. Based in São Paulo, it was founded by Paula Miraglia (who holds a PhD in Social Anthropology and is a social scientist), Renata Rizzi (who holds a PhD in Economics and is an engineer) and Conrado Corsalette (a journalist who has worked for Estadão and Folha de S.Paulo ${ }^{4}$ as a reporter and editor). Rizzi and Miraglia had never worked in journalism. The idea of balance is central to Nexo's discourse, which aims to be a place that reaffirms the possibility and importance of debate in Brazil (Donini, 2017), seeking to "contribute to the public debate, with qualified information, and a lot of evidence" (Donini, 2017, online, our translation).

Marina Menezes, executive editor of Nexo, explained the newspaper's proposal in an interview: "to put factual coverage aside and rely on contextual journalism, conducted by professionals from different areas, that explains the news through interactive and databased multimedia reports" (Estarque, 2017, online, our translation). Menezes claims that there is another way to view what "news" is due to 
the multidisciplinary nature of employees and the fact that there is no old agenda proposing new approaches to old information. The juxtaposition with explanatory journalism, inspired by the American website Vox ${ }^{5}$, makes Nexo relevant in Brazilian journalism as it is the first explanatory vehicle in the country to gain national and international distinction.

It is a challenge for one to find their niche in the Brazilian journalistic ecosystem. As Miraglia points out, Nexo rejects the label of alternative media because it does not want to build its identity in opposition to another (Donini, 2017). For Spagnuolo (2016, online, our translation), Nexo "has no expressed political inclination, it does not uphold an agenda of activism, it does not belong to or have any ties to any major media group, and it provides general coverage". He considers it to be one of the few new Brazilian journalistic sites to produce daily content (not aimed at thematic niches) that does not practice "activist journalism". There are at least three projects that help map out the network in which Nexo is inserted. Perhaps the most symbolic one is the "Festival $3 \mathrm{i}$ - Jornalismo Inovador, Inspirador e Independente (Innovative, Inspiring and Independent Journalism)", organized primarily by digital native initiatives (Agência Lupa, Agência Pública, BRIO, JOTA, Nexo, Nova Escola, Ponte Jornalismo, Repórter Brasil, ((o))eco, Congresso em Foco, Énois, Marco Zero Conteúdo, Poder360, Projeto Colabora e Google News Lab) 6 . Focusing more on ideas of finance and sustainability, business models, technology and journalism, polarization on social networking sites, diversity in newsrooms, and misinformation, the festival offers a space for a new generation of enterprising journalists to emerge. Thus, Nexo fits into a movement of entrepreneurial journalism (Deuze, 2017), one marked by innovation (Bertocchi, 2017) independence (Muniz Jr., 2017), and professionalism, but on a different scale from large companies.

The two other projects establish a network between Nexo and consolidated vehicles in the journalistic field. Impacto.jor is an initiative to measure the impact of journalism on people's lives through software which identifies performance metrics such as changes in public policies, investigations of or repercussions from politicians. It is partnered with Google News Lab, the Institute for the Development of Journalism (Projor), consolidated national media companies such as Folha and Veja, the regional newspaper Gazeta do Povo, and Nova Escola, a publication linked to a foundation. Nexo also participates in the Credibilidade (Credibility) Project, alongside traditional vehicles and startups, which develops tools and techniques for quality and 
credibility in digital journalism. Nexo appears to align itself with a network of newspapers that reinforce the discourse of professionalism, and distances itself from the discourse of counter-hegemony.

Nexo can be considered a digital native startup (Anderson et al., 2016). The idea of innovation is very present in the company's discourse, marked by the constant search for innovation and experimentation and the challenge of growing and being sustainable (Festival 3I, 2017). Miraglia believes that the journalistic crisis is not only a financial one, but also one of credibility, of an editorial nature, of format and of relationship with readers (Festival 31, 2017; Donini, 2017). The editorial reinvention, which Miraglia believes is necessary, must be restructured in the professional sphere. The staff is comprised of about 40 professionals from different areas such as reporting, infographics, video, research/data, technology, art, business and strategy. Integration between the nuclei, such as writing, art, technology and data, is highlighted.

Initially sustained by subscribers and the initial contribution of the founders, Nexo received an investment in 2019 from the philanthropic organization Luminate. The American organization has an extensive portfolio of independent publishers funded, such as Chequeado (Argentina), Correctiv (Germany), Frontier Myanmar (Myanmar), Hromadske TV (Ukraine), Metta (Kenya), News Deeply (USA) and Agência Pública (Brazil). Miraglia highlighted the budget as key for expanding the business and bringing innovations (Pacete, 2019). As Nunes and Canavilhas (2020) point out, the lack of investment in innovation by the media means that many initiatives turn to support organizations for help.

Nexo is active on several social media platforms through its website and newsletters. The newspaper produced four of these newsletters during our research period: a_nexo (released Mondays to Fridays), Seleção da semana (Saturdays), O que estamos lendo (sent to subscribers on Sundays) and Nos Eixos (focusing on data visualization), the last one released at the end of our analysis. At the time of our evaluation, the website had 16 sections: Expresso (Express), Explicado (Explained), Gráfico (Graphic), Vídeo (Video), Interativo (Interactive), Reportagem (Report), Entrevista (Interview), Serviço (Service), Ensaio (Essay), Podcast, Estante (Bookshelf), Especial (Special), Externo (External), Acadêmico (Academic), Colunistas (Columnists) and Profissões (Professions). During our analysis, an additional section was added: Léxico (Lexicon). The site also addressed nine themes: 
Politics, Economy, International, Society, Culture, Health and Science, Environment, Technology and Sports. Unlike traditional vehicles, the sections do not refer to editorials such as politics, economics and culture. These editorials are linked to the themes.

\section{Methodology}

The content analysis started by reading the website and identifying content that could provide data in order to meet the objective. This was when we identified the 16 sections (15 of which are accessible through the menu) and nine themes. These two content groupings provided us with the instruments for analysis. We also chose to observe the newsletter and the Facebook page. This was done because we needed other ways of entering the site other than direct access. Facebook was an important source for accessing the site, the most popular of all the social networks, and although the newsletter did not account for a large number of the accesses (about $1 \%$ on computers), it was important to analyze since curatorial newsletters have been growing as a journalistic practice (Camargo, 2015), and Nexo newsletters have been used as a reference for other vehicles (Lüdke, 2017).

There are five stages of analysis. Data for three of these stages was collected off the website: the analysis of sections and themes, analysis of the homepage, and the analysis of the articles. In addition, we analyzed the Facebook page and the newsletters (which we received by email). Data collection took place over a two-week period, between September $11^{\text {th }}$ and $24^{\text {th }}, 2017$. Data was always collected at $11 \mathrm{pm}$, screenshots were taken with Google Chrome's Nimbus Screenshot \& Screen Video Recorder, and were then stored and entered into a spreadsheet.

For the first stage, where we analyzed sections and themes, we surveyed the content in each section listed on the home menu and checked the themes which they belong to. An overview was obtained of how much information was produced for each section and theme, so as to guide other reflections and seek inferences about the articulation between sections, themes, format, and journalistic genre and modalities.

The second stage involved analyzing the homepage, which was divided into 15 areas. Each had its own peculiarities, making it necessary to pay attention to different aspects (Fig. 1). We sought to understand which sections and which themes were highlighted in each area, and what kind of content flowed through the homepage. For this, 
we analyzed what was on the site's homepage at the time of collection. For the analysis of the Facebook page, we identified content published by the Nexo page by highlighting which sections and themes were emphasized and analyzing how the platform, as a device, shaped the dissemination of information by using links to the website and multimedia materials on the platform (Fig. 1).

In the fourth stage, we analyzed three newsletters (a_nexo, Seleção da semana and $O$ que estamos lendo), in order to identify which sites Nexo established relationships with, which hierarchical editorial movements were carried out, and which themes were addressed in different areas (Fig . 1).

Figure 1 - Content analysis steps for analyzing sections and themes, homepage, Facebook page and newsletters

\section{ANALYSIS OF SECTIONS AND THEMES}

- What content was published in the section on the day

of analysis?

- What theme does that content belong to?

\section{ANALYSIS OF HOMEPAGE}

AREA A - TOP STORIES

- What is the content in the area?

- What section does it belong to?

- What theme does it belong to?

- When was it published?

AREA B - EM ALTA

(MAJOR STORIES)

What is the content in the area?

- What section does it belong to?

- What theme does it belong to?

When was it published?

AREA C - OTHER TOP STORIES

- What is the content in the area?

- What section does it belong to?

- What theme does it belong to?

- When was it published?

AREA D - OTHER STORIES I

- What is the content in the area?

What section does it belong to?

- What theme does it belong to?

-When was it published?

AREA E - COLUMNISTS

(COLUNISTAS)

- What is the content in the area?

-What theme does it belong to?

- When was it published?
AREA F MAIS RECENTES

(MOST RECENT)

What is the content in the area?

AREA G - GRÁFICO (GRAPHICS)

- What is the content in the area?

- What theme does it belong to?

- When was it published?

AREA H - OTHER STORIES II

- What is the content in the area?

- What section does it belong to?

- What theme does it belong to?

- When was it published?

AREA I - NEXO RECOMENDA (NEXO RECOMMENDS)

- What is the content in the area?

- What theme does it belong to?

- What is the original site?

- What is the publication's profile? Is it a digital native? Independent or traditional?

AREA J - ACADÊMICO

(ACADEMICS)

- What is the content in the area?

- What theme does it belong to?

- When was it published?

\section{FACEBOOK ANALYSIS}

- What content was published?

- What section does it belong to?

- What theme does it belong to?

-When was it published on the site?

- What sharing strategy was used? A link to the site? A

static image, moving image, or video included on

Facebook?

Source: prepared by authors, 2018 .
AREA K - HITS (THE MOST READ)

- What is the content in the area?

- What section does it belong to?

- What theme does it belong to?

- When was it published?

AREA L - VÍDEO (VIDEO)

- What is the content in the area?

- What theme does it belong to?

- When was it published?

AREA M - ÚLTIMAS POR TEMA

(LAST STORIES BY THEME)

- What themes are highlighted?

AREA N - IMPERDÍVEIS (MUST SEE)

- What is the content in the area?

- What section does it belong to?

- What theme does it belong to?

- When was it published?

AREA O - ÍNDEX (INDEX)

- What topics are highlighted?

- What theme do they belong to?

\section{NEWSLETTER ANALYSIS}

- Which newsletter was analyzed ("a_nexo", "Seleção da semana", or "O que estamos lendo")?

- What was the content published?

- Published in which area of the newsletter?

- Which section of the newsletter does it belong to?

- What theme does it belong to?

- On which site was it originally published?

- What is the publication's profile? Is it a digital native? Independent or traditional? 
Lastly, at least one ${ }^{7}$ article was selected from each section of the menu that featured content published during the 14-day data collection period. The evaluation was primarily of a qualitative nature, seeking to understand how the potential of the internet was used (Fig. 2). Hypertextuality was analyzed using Barbosa and Mielniczuk's tool (2011), and identified connections between the analyzed material and other content and websites in terms of quantity, positioning and destination of the links. Interactivity and how it articulates with content was studied by the use of selective interactivity resources (reader interaction with content such as buttons, personalization and indexes) and communicative interactivity resources (interaction between individuals such as comments, studies and submitting questions), as per Rost's proposal (2014). In order to evaluate memory, we started with Palacios and Ribas (2011) and took into account the nature of the links, with functions of historical recovery, contextualization, documentation or expansion. Multimediality was analyzed checking the presence of static image, moving image, audiovisual, audio and infographics, and identifying the authorship, function and resources used. 
Figure 2 - Steps for content analysis of material

\section{ANALYSIS OF NEWS STORIES}

INTERACTIVITY
SELECTIVE INTERACTIVITY
RESOURCES
$\square$ indices
$\square$ play/pause buttons
$\square$ search engines
$\square$ changes to interface by readers
$\square$ sharing options
$\square$ visual element settings
$\square$ chosen alternative settings
$\square$ other
COMMUNICATIVE INTERACTIVITY
RESOURCES
$\square$ comment space
$\square$ searches
$\square$ reader Questions
$\square$ email address of article writer
$\square$ content submission
$\square$ corrections
$\square$ other

\section{HYPERTEXTUALITY}

NUMBER OF LINKS: LOCATION OF LINK

$\square$ in the text

$\square$ outside the text

LINK DESTINATION

$\square$ this site

$\square$ other site

\section{MEMORY}

NUMBER OF LINKS:

WHAT KIND OF LINK

$\square$ historic recovery

$\square$ contextualization

$\square$ documentation

$\square$ expansion

\section{MULTIMEDIALITY}

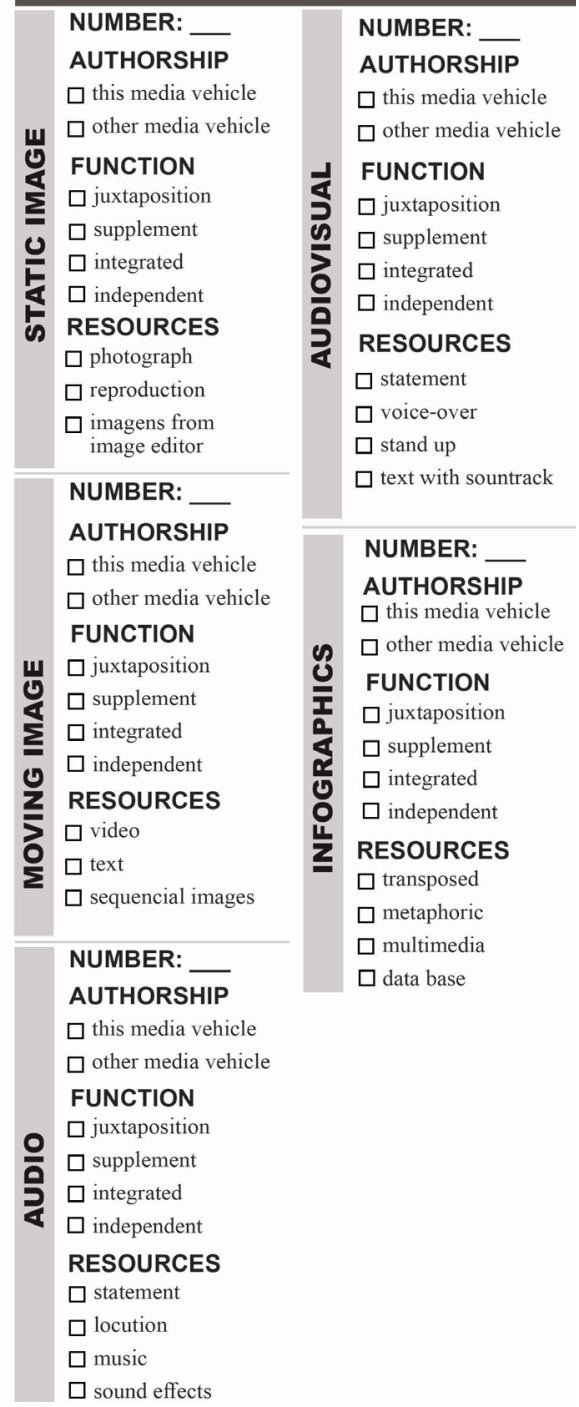

Source: prepared by authors, 2018. 


\section{The shape of information in Nexo}

The analysis allowed us to highlight ways that Nexo shapes journalistic information. Some of the most relevant findings from our investigation are presented below.

Most of the content (73.4\%) comes from the Expresso section and the themes Society (36.3\%) and Politics (34.7\%) accounting for $71 \%$ of the material. These numbers make sense considering the name of the section: Expresso (Express). After all, the name of this section establishes a pre-agreement with the reader (Mouillaud, 1997), and it prioritizes delivering content quickly and to the point. The content in Expresso required less production time as they did not use many interactive and multimedia resources or conduct long investigations. They also required less time to consume as the texts are presented in the traditional format. In addition, they contained current news, more so than other sections. They produced news on a daily basis and therefore needed to be more frequent. This is also why they contained many issues regarding society and politics.

We noticed a cross-section of themes and sections, the main form for grouping content being the sections - related to formats (reporting, essay, etc.) and modalities (video, podcast, graphics) - and the themes, a secondary access. While editorials, sections and themes in traditional newspapers are all part of journalistic universality, Nexo broke from this by prioritizing formats and modalities.

The topicality of the content, in some cases, was not the most relevant factor in deciding which materials to select from the homepage, but the possibilities of interactivity (Interativo) and multimedia (gráfico, vídeo) were. In addition, due to the wide range of content offered on the homepage, older content was easily accessed, different from what occurs on traditional journalistic sites.

An articulation of several devices was observed, such as website, Facebook and newsletter which, in their own way, conformed editorially and triggered different processes of producing meaning. One thing we noticed was the quickness of Facebook posts. $55.94 \%$ of the analyzed material was published on the same day both on the website and the social network, while $38.46 \%$ was published on the page the following day. Only $4.2 \%$ of the posts contained multimedia content directly incorporated into Facebook. We noticed that production was not geared towards consumption 
on social media platforms - at the time of this analysis Nexo was not even using Facebook Instant Articles. On the contrary, it seemed to prefer to strengthen its brand and attract readers to its website and, consequently, increasing subscriptions - indicating an option for centralizing content at the expense of dispersion Jenkins et al., 2014). For this, it used links outside of Facebook, present in $97.9 \%$ of the posts and always referring to its website.

In a 24/7 society, Nexo seeks to organize the flow of information through newsletters. A_nexo told its readers, through the use of imperative verbs in the section titles, what they needed to survive: understand what is at stake (Entenda o que está em jogo), be aware of this (Fique atento a isto), look beyond the border (Olhe além da fronteira), slow down (Desacelere), get inspired (Inspire-se). In order to "understand what is at stake", one has to read political news, and to "be aware" of social issues and economics and "look beyond the border", as the most prevalent themes in the sections showed. But if society is accelerated, Nexo also seemed to value the opposite: one had to "be inspired" and "slow down", and according to the data, it understood that cultural content was important for that.

In this sense, analyzing the temporality that guided a_nexo is also relevant. Newsletters establish a regular periodicity in a medium of continuous flow and instantaneousness. News for immediate consumption is retrieved the next day. In the case of a_nexo, 81.35\% of its articles were published one day prior or on the same day they were submitted. Inspire-se (Get inspired) and Desacelere (Slow down) were sections that worked with less recent content.

Nexo also configured information by curating the contents of various vehicles, rearranging information, and composing a network of relationships, proving to be a newspaper which is integrated into a large ecosystem where one depends on the other. Avoiding the "alternative" label, it took on a complementary role to traditional newspapers. It resorted to information produced by large companies, distancing itself from the discourse of counter-hegemony, adhering to the logic of cooperation, sharing and connectivity (Jenkins, 2009), and legitimized its status as an organizer of chaotic information, both through newsletters and explanatory journalism.

The material explored several modalities which were organized from the sections. Static images, moving images, audiovisual, audio and infographics were identified. Various journalistic formats were 
also explored (interviews, columns, essays, reports) and linked to genres, also organized from the sections. Explanatory journalism predominated, but the opinionated genre was also present.

A lot of hypertext and memory was used to contextualize and explain, with links found in almost all analyzed content. The explanatory journalism gained strength through the links that contextualized, documented, and recovered stories. This was evident in Expresso and Explicado, the two sections that identified as more dedicated to explanatory journalism. In these cases, Nexo looked on journalistic sites, for documents on university and online library sites in order to access the memory to explain. The use of hypertext was a strategy for building content: a research and curation of information, using other vehicles, in which Nexo looked for foundations to offer explanations. Sources were rarely interviewed or cited in the text.

Multimedia and interactivity were explored in terms of the innovative content they offer. Multimedia is also presented as a relevant explanatory resource, especially for graphics and videos. Only two of the materials we analyzed did not have resources outside the written text. Even though most of the analyzed materials used static images to complement the narratives, Nexo really solidified its multimodal nature through the use of moving images, audio, infographics and audiovisuals. Other interesting uses of modalities can be found in the sections Ensaio and Explicado which were integrated into multimedia narratives, and in the sections Podcast, Gráfico and Vídeo, which used them independently. The Ensaio section used animation to help visualize information and the Explicado section included songs taken from Spotify in one of its articles about birth control pills. Infographics, podcasts and videos are strategies of current journalism production which, in recent years, has seen podcasts and videos rise in popularity, as well as the consolidation of data-driven journalism.

Interactivity was hardly used on the site, different from what discourse from and about Nexo has stated. In addition to play and pause buttons for videos and audio files, the sections Acadêmico and Explicado offered a selective form of interactivity, using indexes which allow readers to guide their own reading, a useful resource for longer texts. Forms of communicative interactivity, like comments, were explored on other platforms such as Facebook. The content registering the highest level of interactivity on the site could be found 
in the section called Interativo (Interactive); a news game which the reader could interact with. This proposal was made possible through the integration between professionals and a flexible Content Management System. That is not to say that, with the exception of news games, the site did not have innovative interactive materials. It did, in fact, have other interactive content such as "Qual é o grau de discordância e concordância entre os ministros do Supremo (How much do Supreme ministers disagree or agree with each other)" a report included in the Especial section. However, this type of content was not regular and was often included in the Interativo section, which was characterized by material with no journalistic hooks and took on the tone of magazine journalism, one example being "Você consegue adivinhar que obra é esta a partir apenas de suas cores? (Can you guess what work of art this is just from its colors?)". This is not explanatory journalism.

Lastly, we assessed how the characteristics of a newspaper, as Nexo defines itself, apply to Nexo. For Groth (2011), the newspaper is characterized by its topicality, periodicity, publicity and universality. As stated, changes in the perception of space and time imply changes to how these intrinsically linked characteristics are understood.

The topicality, an obsession of traditional newspapers, with the imperative of instantaneity, seems to be something Nexo considers secondary, as is evident by the analyzed materials and its homepage. The Expresso section, which mostly covers hot topic news was, in fact, the site's most prolific section. But a lot of content from other sections distanced itself from the temporal hook, being more in line with magazine journalism. Periodicity (which is similar to instantaneity on the Internet) was also something Nexo tended to stray from. Current issues were addressed in a timely manner but not with the regular frequency of traditional newspapers. When choosing to explain events, the site did not have to periodically come back with the latest information. A single manifestation was enough to place an element in an enriched timeline. On the other hand, with its newsletter, Nexo followed regular printed press periodicity, breaking from the flow of the web. Universality was visible on the website. While it is common for digital natives to cover niches, Nexo went in a different direction. It talked about the Brazilian census of 1872, about Brazilian pop singer Anitta, about Operation Car Wash (the Brazilian Federal Police investigations into money laundering and corruption). Universality was framed by 
nine themes and the sections which guide the reader. Explanatory journalism was directly linked to the universality of journalistic content. The more plentiful the world becomes, the more important it is for citizens to understand what is happening. Lastly, publicity can be thought of based on the strategy used for multiplatform content distribution. Social networks were an important channel for Nexo to disseminate its material, but it was through its website and newsletters that other information was made public. Distribution, particularly on Facebook, requires one to think about propagation strategies (Jenkins et al., 2014) on a platform that the vehicle does not own.

Our findings allow us to reflect on ruptures and constants in the journalistic field in terms of convergence. The way in which journalistic information is presented is influenced by processes that must be understood within the broader framework outlined here. Elements such as: the acceleration of society; dischronicity; the emergence of mass self-communication media; flexibility; and the establishment of networks are important when thinking about changes in journalism.

\section{Final considerations}

In a 24/7 society marked by an overabundance of information, the rise of Nexo poses a question about the information genre and the role of journalists. The journalism of large media conglomerates is important for producing news and reports on a large scale. As highlighted by Spenthof (2015), without an organizational environment there is no quality information in great volume. Without this production, Nexo would find curatorial material scarce and the links would have less history to recover. However, the production of information does not seem to be sufficient for today's society. When they are in excess and consumption is asynchronous, curation and explanation are important. An ecosystem is seen with hegemonic and counter-hegemonic vehicles, traditional and independent newspapers, journalists, amateurs, the public and machines depending on each other (Anderson et al., 2013).

Innovation comes from narrative forms, production processes, and the circulation and consumption of information (Martins, 2017). As Barbosa (2012) proposed, databases, mobile devices and 
multiplatform journalism reshape convergence journalism and can provide context and depth. Projects like Nexo are a way of thinking about the crisis in journalism as not just financial, but also taking into account the crisis in editorial and credibility (Mick \& Tavares, 2017), making it necessary to reinvent formats and relationships with readers.

Nexo, with its explanatory proposal, based on the activation of memory, hypertextuality, multimedia and interactivity, seeks to contribute to the public debate. New initiatives can possibly strengthen essential values in the journalistic field and renew practices. Identifying how the web can collaborate in this is an important step.

This paper reflects on the configuration of journalistic information in a digital native from the notion of a device, and the journalistic product at a time of convergence as a multidimensional phenomenon with implications in the editorial world. Since the content of the message and its form are inseparable, and the configuration of the message by each device triggers different semiotic systems, it is essential to reflect on this editorial shaping process. In terms of the object, a digital native was analyzed in order to recognize it as an important part of the current journalistic ecosystem. A possibility for future investigations would be to reapply the method in comparative studies, and analyze media vehicles of all sizes. It is noteworthy that, given the centrality of explanatory journalism in the analyzed object, the discourse analysis can be useful to other approaches. Likewise, methodologies that make it possible to analyze the production process more appropriately, such as ethnography or interviews, are presented as other investigation possibilities.

NOTAS

1 The full research can be found at http://hdl.handle.net/10183/ 178383

2 We chose Deuze's (2017, p.11, our translation) definition of startups: "organizations built primarily from their presence on the web, with no formal connection to traditional journalistic companies and which seek to be recognized by their peers as journalistic". 
3 www.nexojornal.com.br

4 Folha de S. Paulo and Estadão (or O Estado de S. Paulo) are the first and third largest circulation newspapers in Brazil, respectively, according to 2019 data from the Communication Verifying Institute.

5 www.vox.com

6 With the exception of Google News Lab, the initiatives listed here are mostly Brazilian digital native vehicles dedicated to investigative journalism, some of which focus on topics such as politics, human rights, the environment and legal issues. They are not linked to large media conglomerates and are presumably not profit oriented or linked to institutions related to education, environment or labor issues, for example.

7 Some sections have different types of content, requiring us to select more than one news story in order to better understand the possibilities of shaping the information. This is the case with the section called Estante, which is subdivided into the sections of Trechos (Excerpts) and Favoritos (Favorites).

\section{REFERENCES}

Anderson, C. W., Bell, E., \& Shirky, C. (2013). Jornalismo pós-industrial: adaptação aos novos tempos. Revista de Jornalismo ESPM, (5), 30-89.

Anderson, C. W., Downie Jr., L., \& Schudson, M. (2016). The news media: What everyone needs to know. New York, NY: Oxford University Press.

Barbosa, S. (2012). Agentes de inovação, renovação e de reconfiguração para o jornalismo em tempos de convergência. Cibercomunicación, (1), 1-8.

Barbosa, S., \& Mielniczuk, I. (2011). Ferramenta para análise de hipertextualidade em cibermeios. In M. Palacios (Ed.), Ferramentas para análise de qualidade no ciberjornalismo (pp. 37-50). Covilhã, Portugal: LabCom.

Barsotti, A. (2014). Transformações contemporâneas nas práticas jornalísticas: o jornalista on-line como mobilizador de audiência. Revista da Associação Nacional dos Programas de Pós-Graduação em Comunicação. 17(1), 1-20. Retrieved from www.e-compos.org.br/ecompos/article/download/1080/761/ 
Barsotti, A., \& Aguiar, L. (2017) A invisibilidade da home page e as mudanças nos modos de leitura das notícias. Proceedings from XXVI Encontro Anual da Compós. São Paulo, Brazil: Compós. Retrieved from <https://goo.gl/G4PgLq>.

Bell, E., \& Owen, T. (2017, march 29). The Platform Press: How Silicon Valley reengineered journalism. New York, NY: Columbia Journalism School. Retrieved from www.cjr.org/tow_center_reports/platformpress-how-silicon-valley-reengineered-journalism.php

Bertocchi, D. (2017). Startups de jornalismo: desafios e possibilidades de inovação. Contemporânea: Comunicação e cultura, 15(1), 101117. Retrieved from <https://bit.ly/2JYlsCW>.

Camargo, I. (2015). Caracterizações, processos de produção e tendências do jornalismo em mobilidade. (master thesis, University of São Paulo). Biblioteca Digital USP.

Canavilhas, J. (Ed.). (2014). Webjornalismo: 7 caraterísticas que marcam a diferença. Covilhã, Portugal: Livros LabCom.

Carr, D. (2014). For Email Newsletters, a Death Greatly Exaggerated. Retrieved from <https://goo.gl/URQvPt>.

Castells, M. (2015). O poder da comunicação. São Paulo/Rio de Janeiro, Brazil: Paz e Terra.

Charaudeau, P. (2009). Discurso das mídias. São Paulo, Brazil: Contexto.

Charron, J., \& De Bonville, J. (2016). Natureza e transformação do jornalismo. Florianópolis, Brazil: Insular; Brasília, Brazil: FAC Livros.

Crary, J. (2014). 24/7: Capitalismo tardio e os fins do sono. São Paulo, Brazil: Cosac Naify.

Deuze, M. (2017). Considering a possible future for digital journalism. Revista Mediterránea de Comunicación, 8(1), 9-18. DOI: 10.14198/ MEDCOM2017.8.1.1.

Deuze, M., \& Witschge, T. (2015). Além do jornalismo. Leituras do jornalismo, 2(4), 1-31. Retrieved from www3.faac.unesp.br/ leiturasdojornalismo/index.php/leiturasdojornalismo/article/ view/74

Donini, M. (2017, Oct. 12). Nexo Jornal reafirma a possibilidade do debate público. Farol Jornalismo. Retrieved from <https://goo. $\mathrm{gl} / 3$ Ajwhq $>$.

Estarque, M. (2017). Além da notícia: Site brasileiro inova ao investir em jornalismo de contexto e multidisciplinar. Knight Center. Retrieved 
from <https://goo.gl/PCU2eq>.

Fagerlund, C. (2015). Back to the future: Email newsletters as a digital channel for journalism. London, United Kingdom: Polis.

Festival 3I. (2017). \#Festival3i - Dia 1 [video file]. Retrieved from <https://goo.gl/S83Yv6>.

Forde, K. (2007). Discovering the explanatory report in American newspapers. Journalism Practice, 1(2), 227-244. DOI: $10.1080 / 17512780701275531$.

Groth, O. (2011). O poder cultural desconhecido: Fundamentos da ciência dos jornais. Petrópolis, Brazil: Vozes.

Gruszynski, A. (2011). A forma que (in)forma: o projeto gráfico do jornal impresso na contemporaneidade. Proceedings from XXXIV Congresso Brasileiro de Ciências da Comunicação (1-16) São Paulo, Brazil: Intercom. Retrieved from <https://goo.gl/gyVy4l>.

Gruszynski, A. (2016). Dispositivos de leitura no cenário de convergência das mídias. In T. Rösing, \& R. Zilberman (Eds.), Leitura: história e ensino (pp. 169-187). Porto Alegre, Brazil: Edelbra.

Han, B. C. (2017). The scent of time: A philosophical essay on the art of lingering. Cambridge, United Kingdom: Polity.

Harlow, S., \& Salaverría, R. (2016). Regenerating journalism: Exploring the 'alternativeness' and 'digital-ness' of online-native media in Latin America. Digital Journalism, (4), 1001-1019. DOI:10.1080/2167081 1.2015 .1135752

Harvey, D. (1992). Condição pós-moderna. São Paulo, Brazil: Ed. Loyola.

Hendrickx, J., Donders, K., \& Picone, I. (2020). Innovating Journalism by Going Back in Time? The Curious Case of Newsletters as a News Source in Belgium. In J. Vázquez-Herrero, S. Direito-Rebollal, A. SilvaRodríguez, \& X. López-García (Eds.), Journalistic metamorphosis: Media transformation in the digital age (pp. 57-68). Cham, Switzerland: Springer.

Hoewell, G. (2018). A configuração da informação no contexto da convergência jornalística: uma análise do Nexo (master's thesis, Federal University of Rio Grande do Sul).

Jenkins, H., Ford, S., \& Green, J. (2014). Cultura da conexão: Criando valor e significado por meio da mídia propagável. São Paulo, Brazil: Aleph.

Jenkins, H. (2009). Cultura da convergência. São Paulo, Brazil: Aleph. 
Kolodzy, J. (2008). Convergence Explained. In A. E. Grant, \& J. S. Wilkinson (Eds.), Understanding Media Convergence (pp. 31-51). New York, NY: Oxford University Press.

Kovach, B., \& Rosenstiel, T. (2014). The elements of journalism: What newspeople should know and the public should expect. New York, NY: Three Rivers Press.

Lüdke, S. (2017, Sep. 28). A reinvenção do jornalismo. Portal dos Jornalistas. Retrieved from: <https://goo.gl/Tt3g8a>.

Machado, E. (2010). Creatividad e innovación en el periodismo digital. Proceedings from II Congreso Internacional de Ciberperiodismo y Web 2.0. Bilbao, Spain: University of the Basque Country.

Martins, E. (2017). Modos e sentidos da inovação no jornalismo. Proceedings from $15^{\circ}$ Encontro Nacional de Pesquisadores em Jornalismo. São Paulo, Brazil: SBPJOR.

Mick, J., \& Tavares, L. (2017). A governança do jornalismo e alternativas para a crise. Brazilian Journalism Research: journalism theory, research and criticism, 13(2), 120-145. DOI: 10.25200/BJR. v13n2.2017.948.

Mielniczuk, L. (2003). Sistematizando alguns conhecimentos sobre jornalismo na Web. Proceedings from $12^{\circ}$ Encontro dos Cursos de PósGraduação em Comunicação. Brasília, Brazil: Compós. Retrieved from <http://bit.ly/2TlgWUM>.

Mouillaud, M. (1997) A crítica do acontecimento ou o fato em questão. In M. Mouillaud, \& S. Porto (Eds.), O jornal: da forma ao sentido (pp. 49-83). Brasília, Brazil: Paralelo 15.

Muniz, Jr., J. (2017). 'É dia de feira': a cena dos microeditores na cidade de São Paulo. Proceedings from Anais do $40^{\circ}$ Congresso Brasileiro de Ciências da Comunicação. São Paulo, Brazil: Intercom. Retrieved from <http://bit.ly/2TI6Jre>

Newman, N. (2020). Periodismo, medios y tecnología: Tendencias y predicciones para 2020. Oxford, United Kingdom: Reuters Institute for the Study of Journalism.

Nexo Jornal. (2017, Oct. 09.). Online Journalism Awards [video file]. Retrieved from <https://goo.gl/hkAZv3>

Norris, A. (2015, June 1). What is explainer journalism? FIPP Connecting Global Media. Retrieved from <goo.gl/MkgQZb>

Nunes, A. C. B., \& Canavilhas, J. (2020). Journalism innovation and its influences in the future of news: A European perspective around Google DNI fund initiatives. In J. Vázquez-Herrero, S. DireitoRebollal, A. Silva-Rodríguez, \& X. López-García (Eds.), Journalistic 
metamorphosis: Media transformation in the digital age (pp.41-56). Cham, Switzerland: Springer.

Pacete, L. G. (2019, Feb. 22). Após investimento, Nexo aposta em diversificação. Meio \& Mensagem. Retrieved from <http://bit. ly/2VFDnW8>.

Palacios, M., \& Ribas, B. (2011). Ferramenta para Análise de Memória em Cibermeios. In M. Palacios (Ed.), Ferramentas para análise de qualidade no ciberjornalismo (pp. 183-205). Covilhã, Portugal: LabCom.

Parisi, P. (1999) Astonishment and understanding: On the problem of explanation in journalism. The New Jersey Journal of Communication, 7(1), 44-64. DOI: 10.1080/15456879909367354.

Pereira, F. H., \& Adghirni, Z. L. (2011). O jornalismo em tempo de mudanças estruturais. Intexto, 24(1), 38-57. Retrieved from <https:// seer.ufrgs.br/intexto/article/viewFile/19208/12362>.

Ramos, D. (2012) Anotações para a compreensão da atividade do 'curador de informação digital'. In E. Saad (Ed.), Curadoria digital e o campo da comunicação (pp. 11-21). São Paulo, Brazil: ECA/USP.

Rost, A. (2014). Interatividade: Definições, estudos e tendências. In J. Canavilhas (Ed.), Webjornalismo: 7 caraterísticas que marcam a diferença (pp. 53-88). Covilhã, Portugal: Livros LabCom.

Salaverría, R., García-Avilés, J. A., \& Masip, P. (2010). Concepto de convergencia periodística. In X. López, \&X. Pereira (Eds.), Convergencia digital: Reconfiguración de los medios de comunicación en España (pp. 41-64). Santiago de Compostela, Spain: Servicio Editorial de la Universidad de Santiago de Compostela.

Salaverría, R. (2015). Mídia e jornalistas: um futuro em comum? Revista Parágrafo, 3(1), 79-83. Retrieved from revistaseletronicas. fiamfaam.br/index.php/recicofi/article/view/297

Schiffrin, A. (2019). Fighting for survival: Media startups in the Global South. New York, NY: Columbia University.

Spagnuolo, S. (2016). O Nexo pode realmente dar certo - se as pessoas pagarem para ver. Farol jornalismo. Retrieved from <https://goo.gl/ UCkDko>

Spenthof, E. L. (2015). Jornalismo e sociedade: O lugar da mediação profissional e da informação tratada como res pública (doctoral dissertation, University of Brasília). Repositório UNB.

Zamith, R. (2018). Quantified audiences in news production: A synthesis and research agenda. Digital Journalism, (6), 418-435. DOI: $10.1080 / 21670811.2018 .1444999418-435$ 
GABRIEL RIZZO HOEWELL. Journalist, Master's Degree in Communication and Information from the Federal University of Rio Grande do Sul (PPGCOM/UFRGS). He is a member of the Laboratory for Editing, Culture \& Design (LEAD) research group. E-mail: gabrielrhoe@gmail.com.

ANA GRUSZYNSKI. PhD in Communication. Professor of the Post-graduate Communication and Information Program at the Federal University of Rio Grande do Sul (PPGCOM-UFRGS). She is a researcher for the Brazilian National Council for Scientific and Technological Development (CNPq). She is a coordinator for the Laboratory for Editing, Culture \& Design (LEAD) research group. E-mail: anagru@gmail.com.

TRANSLATED BY: LEE SHARP 